\title{
2D Electrical Resistivity Imaging (ERI) for Subsurface Evaluation of a Pre-engineering Construction Site in Akure, Southwestern Nigeria
}

\author{
Alagbe Olufemi Adigun*, Faleye Oluseye Emmanuel \\ Department of Applied Geophysics, Federal University of Technology, Akure, Nigeria \\ Email address: \\ oaalagbe@futa.edu.ng (A. O. Adigun) \\ ${ }^{*}$ Corresponding author
}

To cite this article:

Alagbe Olufemi Adigun, Faleye Oluseye Emmanuel. 2D Electrical Resistivity Imaging (ERI) for Subsurface Evaluation of a Pre-engineering Construction Site in Akure, Southwestern Nigeria. International Journal of Environmental Monitoring and Analysis.

Vol. 8, No. 2, 2020, pp. 33-44. doi: 10.11648/j.ijema.20200802.13

Received: August 21, 2019; Accepted: September 10, 2019; Published: May 28, 2020

\begin{abstract}
D electrical resistivity imaging (ERI) and vertical electrical sounding (VES) were integrated to map the subsurface lithology at a pre-engineering construction site in Akure, southwestern Nigeria, in order to ascertain the competence and suitability of the site for engineering structures. Four 2D horizontal profiling (Wenner array) was used to qualitatively study and interprete the geoinformation of the lithological nature of each geoelectric layer within the study site. Four vertical electrical sounding were also conducted using Schlunberger configuration. The VES data were processed and inverted using master curves and WinResist computer software, while the 2D inversion was done using Diprowin. The results of the 2D horizontal profiling revealed that the study area is composed of four subsurface geo-electric layers with resistivities ranging between $6.91 \Omega \mathrm{m}$ to $93.6 \Omega \mathrm{m}$. These results revealed an expansive clay formation to the depth probed. While the VES results showed a three subsurface geo-electric layers with resistivities ranging between $8.4 \Omega \mathrm{m}$ to $640 \Omega \mathrm{m}$ with the second layers where the foundation is supposed to be laid confirmed the presence of clay with resistivities ranging between $8.4 \Omega \mathrm{m}$ to $13.0 \Omega \mathrm{m}$ with depth ranging between $4.9 \mathrm{~m}$ to $7.9 \mathrm{~m}$. The results revealed the site to be an expansive clay formation and showed that shallow foundation may not be feasible or advisable for massive engineering structures because of the presence of clay materials in the area. But small or light engineering structures may be recommended.
\end{abstract}

Keywords: Akure, Expansive Clay, 2D Resistivity Imaging, Pre-foundation, Wetclay

\section{Introduction}

As a result urbanization, recent settlement and expected influx of people into Akure, buildings are springing up in areas which are normally not considered for development are now been developed. These areas include swamp forest, old river paths and flood zones $[1,2]$. However, to reduce the menace of building collapse which usually results in wasted resources and the possible loss of life, pre-foundation studies have been recommended before any structures is laid so that proper foundation design and recommendations can be made for such proposed structure. Engineering design and construction of foundation, especially of buildings, dams, highway routes, and bridges requires a sound knowledge of the subsurface, hence, the need for the builders and engineers to be properly informed on the lithology of the area with a view to advising members of the society the types of engineering structures to be embarked upon.

The properties of soil and rock are the results of the natural processes that have formed them, and man-made events following their formation. The geotechnical experts in designing and constructing facilities are faced with the challenges of using the foundation and construction materials available on or near the project sites. Therefore, the designing and building of such structures requires a thorough understanding of properties of available soils and rocks that will constitute the foundation and other components of the structures [1]. The necessity for site characterization for construction purposes has become very vital due to failure of building and structure collapse throughout the federation, 
which has enormously increased in recent time, leading to loss of valuable lives and properties [3, 4].

The design of a structure which is safe, low maintenance cost and durable depends upon an adequate understanding of the lithology and geotechnics of the subsurface in which the building is erected [5]. Factor such as the lithology of the subsurface plays a major role in the suitability of a site for any particular purposes. The presence of a layer of clay within the subsurface is a danger sign for any individual willing to erect a structure on such a piece of land. The intended structure may out weight the clay and begin to sink, causing the foundation of the building to sink, thereby making the structure above the surface to collapse i.e. the structure crack down from the foundation. Foundation cracks on building occur as a result of differential movement on the building [6-8].

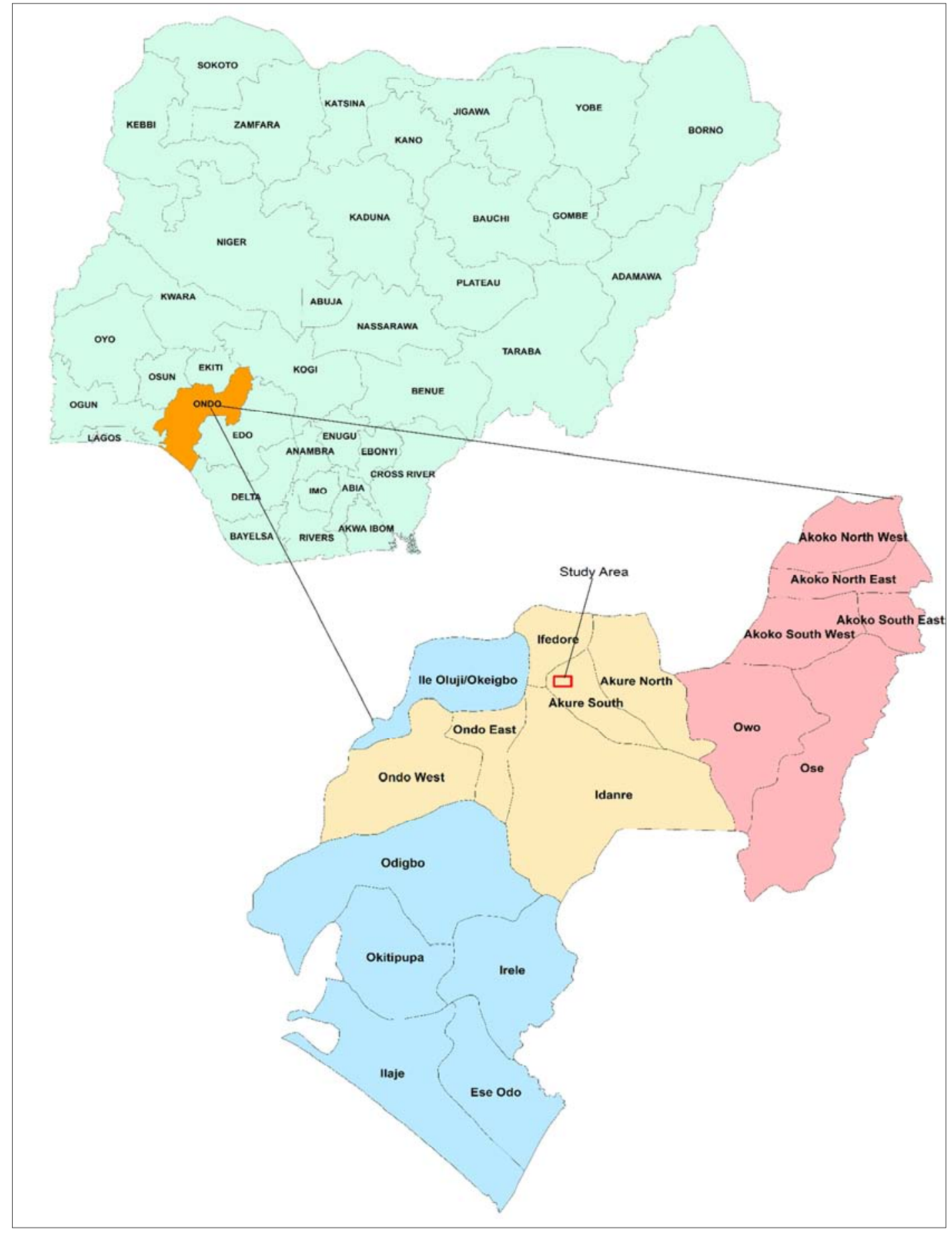

Figure 1. Location map (Map of Nigeria showing Ondo state and study area).

In building construction, poor soil stability is one of the factors that cause havoc. This is because some soils are very sensitive to moisture gain or loss. Certain clay soils for instance, can expand multiple times in volume if they get saturated and 
when there is loss of water in them, they shrink in volume. This expansion and shrinkages of clayey soils cause foundation cracks on buildings shortly after they are built in the process of their settlement. In the areas like the study area (Akure) for example, the near-surface soil is of expansive clay [9, 10], and this (expansive clay) behaves differently than sandy soil. Sandy soil does not expand when it gets wet instead the water fills the air space between the grains of the sand. Because of this, the soil volume does not change and there is little movement of the structures supported by the soil when the soil moisture conditions alternate between wet and dry. Expansive clay soil expands when it absorbs water. Water becomes bound to the clay particles. As the soil goes through wet and dry periods, the soil expands and contracts. Structures sitting on top of the clay soil rise and fall with the soil. If this happened uniformly across the structure, damage to the foundation and finishes from the soil movement would be limited. Unfortunately, uniform shrinking and swelling does not usually happen. The result is "differential" foundation movement, which causes cracking and distress. This study, therefore, intends to identify the lithostratigraphy of the study area, with a view to advising the interested members of the public or society the type of engineering structures to be embarked upon in order to avoid collapse of building. In view of the foregoing, electrical resistivity methods were used to investigate the subsurface stratigraphic relationships or variation of subsurface materials in the study area, with a view to determining the subsurface lithology within the study area and ascertaining the implications of the lithology distribution on engineering structures. And since every engineering structure is seated on geological earth materials [11-13], it is important to conduct pre-construction investigation or study of the subsurface of the proposed site in order to ascertain the strength and fitness of the host earth materials. This pre-foundation study has therefore become necessary so as to prevent loss of valuable lives and properties that always accompany such failures.

\section{Location, Climate and Geology of the Study Area}

The study area is located along Akure-Ilesha highway in the Universal Traversal Mercator (UTM) coordinate of zone 31, Minna datum, the study area is located within Northing 0807835 to $0807895 \mathrm{~N}$ and Easting 0737328 to $0737355 \mathrm{E}$ (Figures 1 and 2).

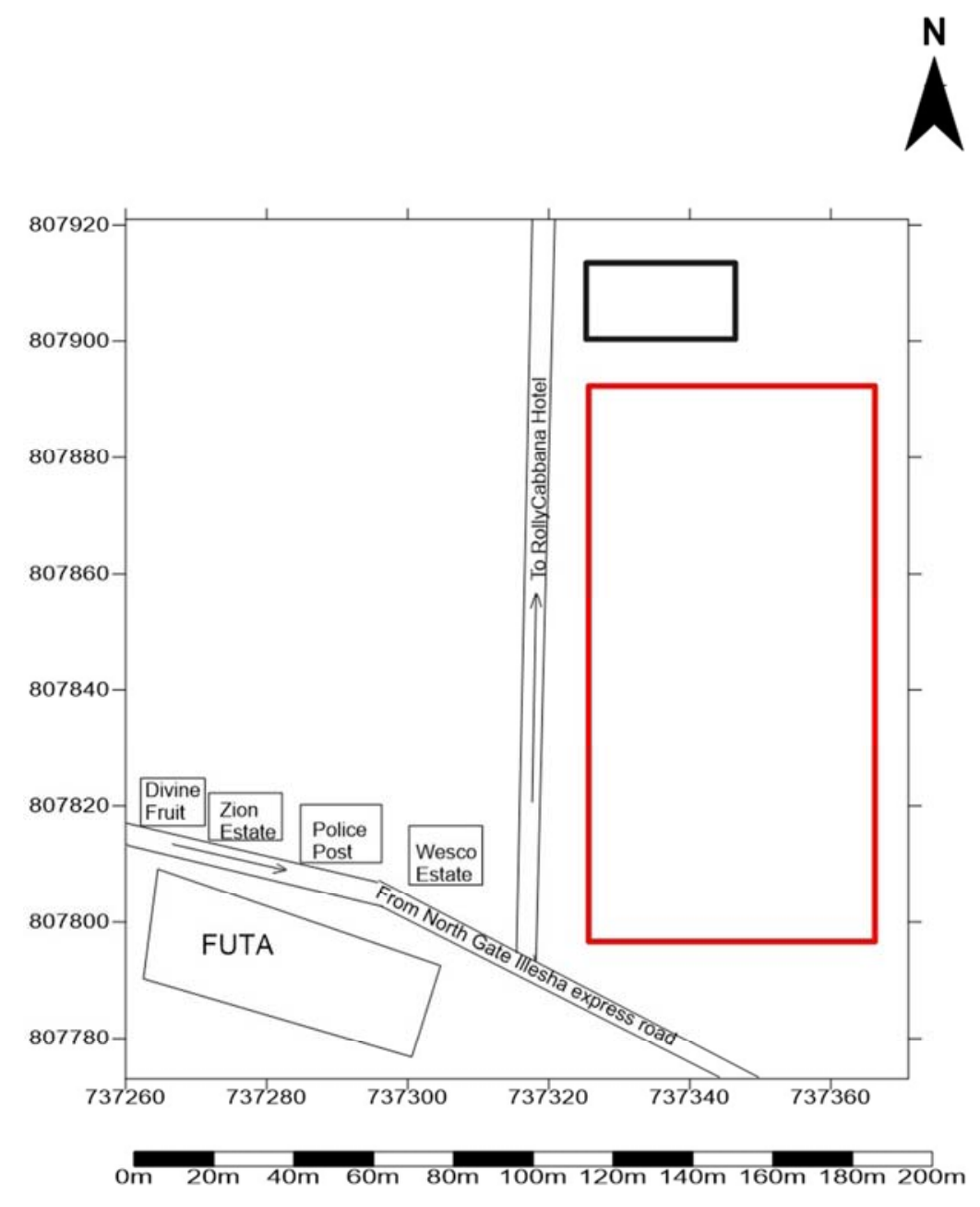

Figure 2. Location Map of the Study Area. 
magmatic and granitic gneisses, quartzite, slightly migmatised meta-sedimentary schist and meta-igneous rocks; charnockite, garbrolic and diorite rocks and the members of the older granite sites, mainly granite, granidiorite and sydenites $[13,14]$. Although the basement rock is concealed within the survey area, it is expected to be made up of migmatite gneiss (Figure 3).

The elevation above sea level of the study area is between
$387 \mathrm{~m}$ and $394 \mathrm{~m}$. The study area is surrounded by evergreen vegetation and it is characterized by two seasons; the wet and dry seasons. The wet season starts around April and ends October with an average annual rainfall of about $1000 \mathrm{~mm}$ to $1700 \mathrm{~mm}$. The dry season starts October starts around November and ends in March. Humidity is relatively high during the wet season and low during the dry season. Temperature varies from $22^{\circ} \mathrm{C}$ to $29^{\circ} \mathrm{C}$.

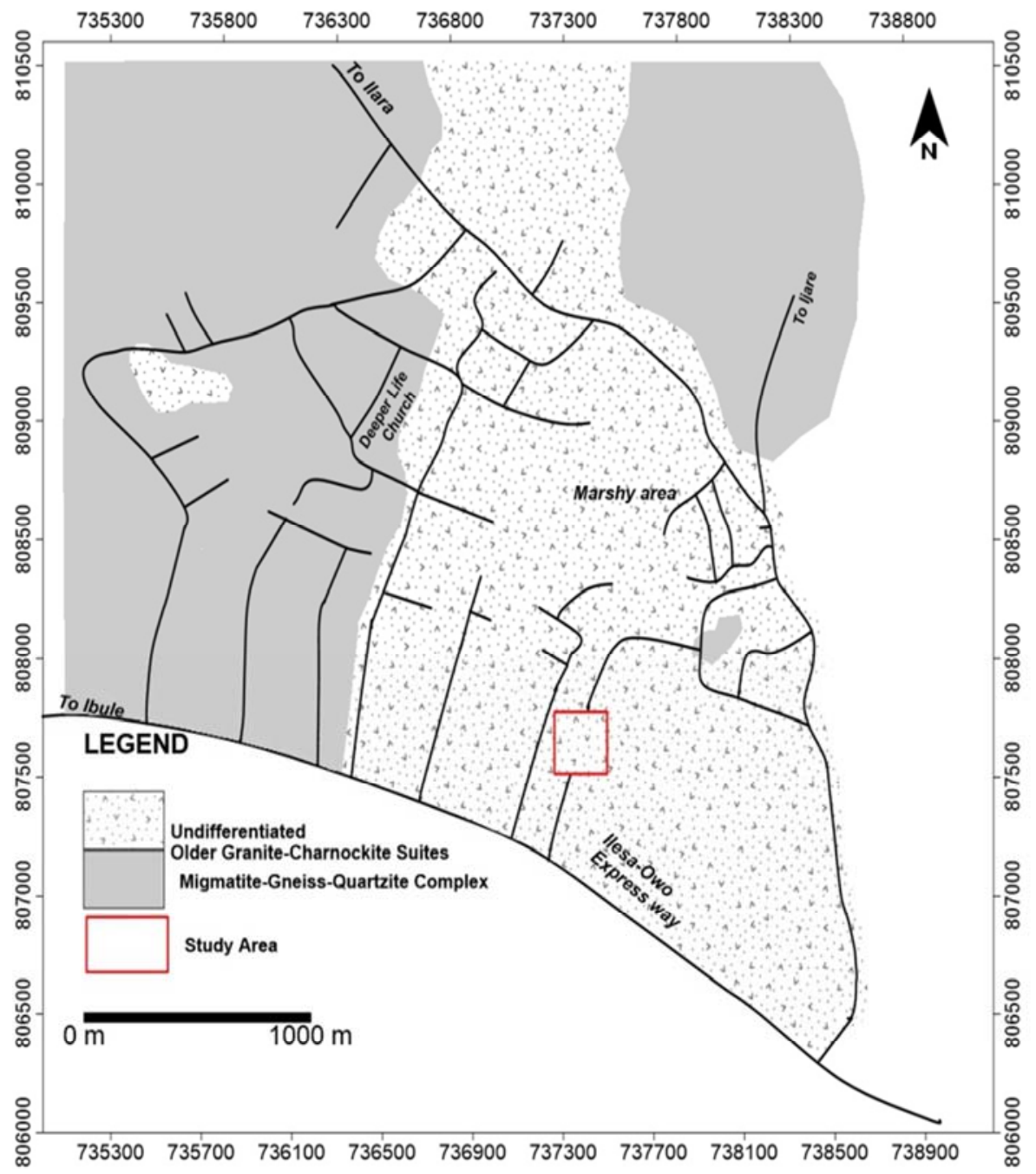

Figure 3. Geological Map of Akure [15] (After Adeyemo, 2015).

\section{Materials and Methodology}

In this research work, the Wenner electrode and Shlumberger electrode configurations were used during the resistivity measurements.

For Wenner electrode configuration, four traverses were established along North-South directions in the study area with electrode spacing of $5 \mathrm{~m}$ and a maximum of $60 \mathrm{~m}$ spread (Figures 5 - 8). Four Vertical Electrical Sounding (VES) was also established and the data obtained from VES was processed and presented as sounding curves (Figures 11-14). A maximum of $A B / 2$ of maximum spread of $90 \mathrm{~m}$ was used. The geoelectric parameters (resistivity, thickness and depth) obtained was appropriately iterated with the use of a commercial computer program called WinRESIT. Geoelectric (Figure 15) section was also generated with the aid of SURFER 12 software.

For the 2D resistivity imaging, the data were processed by using inversion software DIPRO. Basically, the data from these surveys are commonly arranged and contoured in the form of a pseudosection which gives an appropriate picture of the subsurface resistivity. The apparent resistivity of the subsurface can be computed using the following formular: $\rho$ $=2 \pi \mathrm{aR}$, where $\mathrm{a}=$ electrode spacing and $\mathrm{R}=$ resistance. The use of the DIPRO, essentially involves the reading of the field data, inversion of the data using least square inversion procedure to get the true resistivity and the true depth of the 
field resistivity image. Topographic corrections to account for variations in the surface elevation are also included in DIPRO software.

The basic field equipment for this study is the resistivity meter which displays apparent resistivity values digitally as computed from ohm's law. It is powered by a 12 Volt (V)
Direct Current (DC) power source. Other accessories to the Resistivity meter include the four metal electrodes, cables for current and potential electrodes, harmers (four), measuring tapes, writing pads.

Data from the electrical resistivity imaging is presented as pseudo-sections (Figures 5-8).

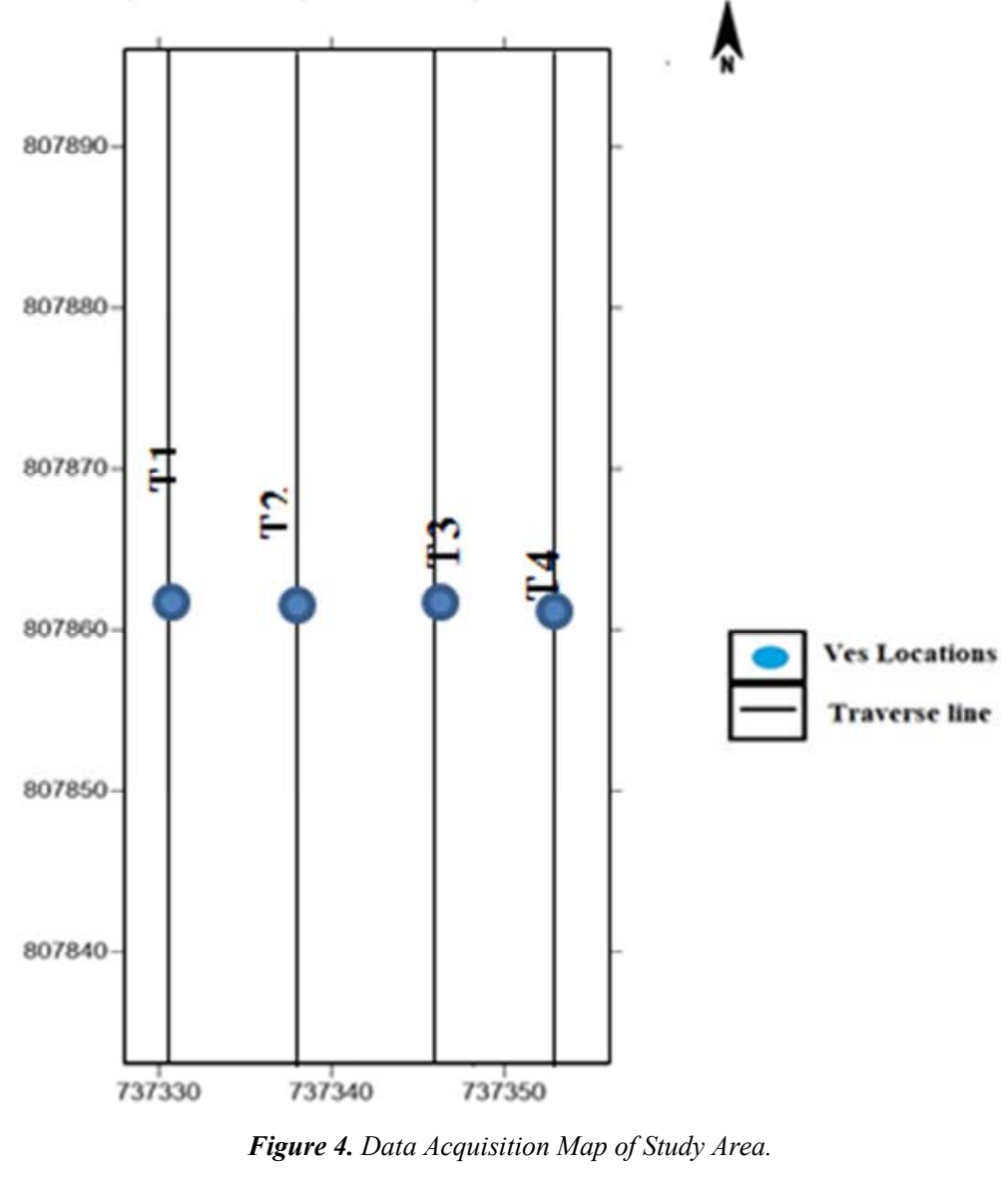

\section{Results and Discussion}

\subsection{D Imaging}

The result of the processed imaging data by dipro are displayed as inverted model representing sections versus depth of the surface along the $2 \mathrm{D}$ resistivity inverse model section of the profile and are presented in figures $(5-8)$. The horizontal scale on the section is the lateral distance, while the vertical scale is the depth (in metres). A maximum spread of $60 \mathrm{~m}$ was modeled on all the profiles.

Traverse 1 (Figure 5) covers a total spread of $60 \mathrm{~m}$ with an electrode spacing of $5 \mathrm{~m}$ and runs in the N-S direction. The resistivity value ranges from $13.4 \Omega \mathrm{m}$ to $77.9 \Omega \mathrm{m}$ along the traverse. Four major layers are observed in this $2 \mathrm{D}$ resistivity structure. The first layer (blue colour) trending in the east to northwest direction with resistivity value ranging from $6.91 \Omega \mathrm{m}$ to $7.83 \Omega \mathrm{m}$ and observed between stations 3 to 12 . It has a uniform distribution between stations 5 to 12, covering a depth of about $2 \mathrm{~m}$, and which reveal peat/unconsolidated wet clay. There is an observed downward extension of this peat/unconsolidated wet clay towards the western direction between stations 3 and 4 to a depth of about $7 \mathrm{~m}$. The second layer (Green) has resistivity value ranging from $13.4 \Omega \mathrm{m}$ to $17.4 \Omega \mathrm{m}$, which reveals clay, has a depth between $2 \mathrm{~m}$ and $5 \mathrm{~m}$. It also trends in the east-west direction and occurring between stations 3 and 12 with a discontinuity as a result of the peat/unconsolidated wet clay intruding into it between station 3 and 4 . The third layer (Red) has a resistivity value ranging from $22 \Omega \mathrm{m}$ to $22.9 \Omega \mathrm{m}$ occurring a depth between $5 \mathrm{~m}$ to $7 \mathrm{~m}$ and this section reveals clay/sandy clay formation. The fourth layer (purple) has resistivity value ranging from $33.1 \Omega \mathrm{m}$ to $77.9 \Omega \mathrm{m}$ and reveals sandy clay.

Generally, traverse 1 appears to have an extensive clay formation which is generally not good enough for engineering purposes. But notwithstanding, light structures could still be recommended with little excavation to a depth of about $3 \mathrm{~m}$ between stations 5 and 12 . Stations between 1 and 4 should be avoided for any engineering structure and if it is to be used it must be with a deep foundation. 


\section{trav_1 (Field Data Pseudosection)}

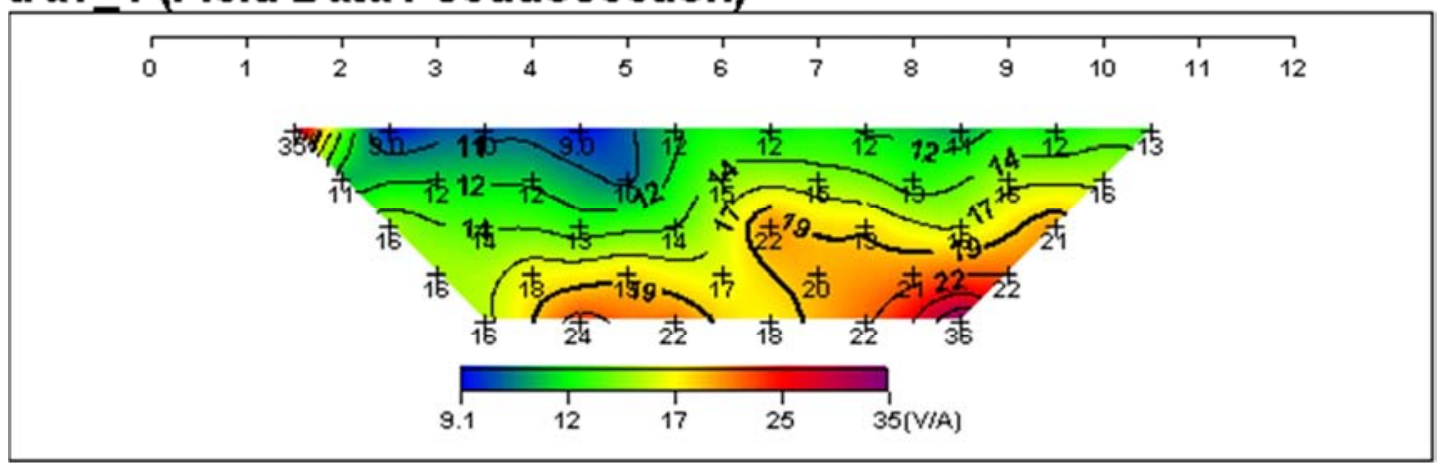

\section{trav_1 (Theoretical Data Pseudosection)}

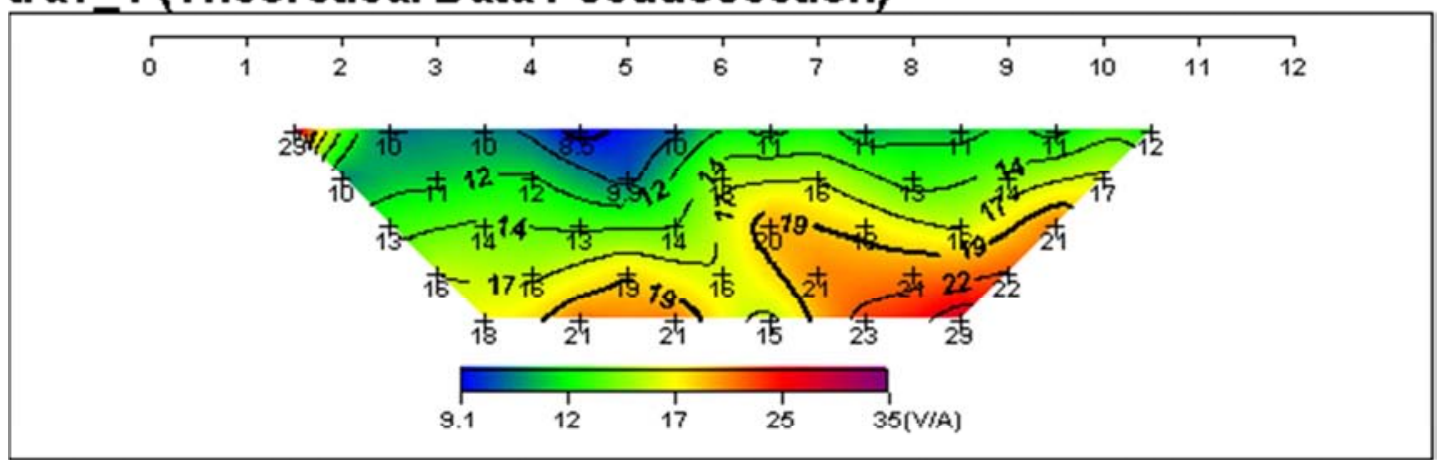

\section{trav_1 (2-D Resistivity Structure)}

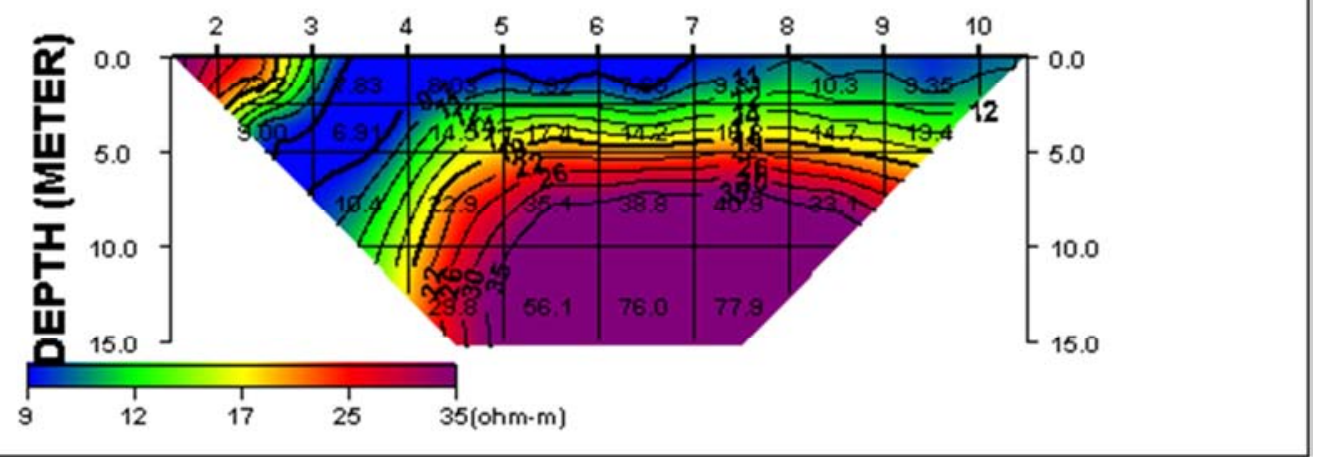

Figure 5. Inverted 2D Resistivity Section Along Traverse 1.

Traverse 2 (Figure 6) covers a total spread of $60 \mathrm{~m}$ with an electrode spacing of $5 \mathrm{~m}$ and runs in the N-S direction. The resistivity value ranges from $8.37 \Omega \mathrm{m}$ to $68.8 \Omega \mathrm{m}$ along the traverse. Four major layers are observed in this $2 \mathrm{D}$ resistivity structure. The first layer (blue colour) is observed at the two edges of the traverse (i.e. at the northwestern and northeastern edges) with resistivity value ranging from $8.37 \Omega \mathrm{m}$ to $9.18 \Omega \mathrm{m}$ and observed between stations 1 to 4 and 7 to 9 , covering a depth of about $2 \mathrm{~m}$, and which reveal peat/unconsolidated wet clay. The second layer (Green) has resistivity value ranging from $12.7 \Omega \mathrm{m}$ to $18.3 \Omega \mathrm{m}$, which reveals clay, has a depth between $2 \mathrm{~m}$ and $7 \mathrm{~m}$ in the western flank and between $2 \mathrm{~m}$ and $6 \mathrm{~m}$ towards the eastern flank. The third layer (Red) has a resistivity value ranging from $31.1 \Omega \mathrm{m}$ to $39.8 \Omega \mathrm{m}$ occurring a depth between $6 \mathrm{~m}$ downwards, occurring between stations 4 and 9 and this section reveals clay/ sandy clay formation. The fourth layer (purple) has resistivity value ranging from $61.5 \Omega \mathrm{m}$ to $68.8 \Omega \mathrm{m}$ and reveals sandy clay.

Generally, traverse 2 also appears to have an extensive clay formation which is generally not good enough for engineering purposes. Again, light structures could also be recommended with little excavation to a depth of about $3 \mathrm{~m}$ between stations 5 and 12. Stations between 1 to 4 and 8 to 9 should be avoided for any engineering structure and if it is to be used it must also be with a deep foundation. 


\section{trav_2 (Field Data Pseudosection)}

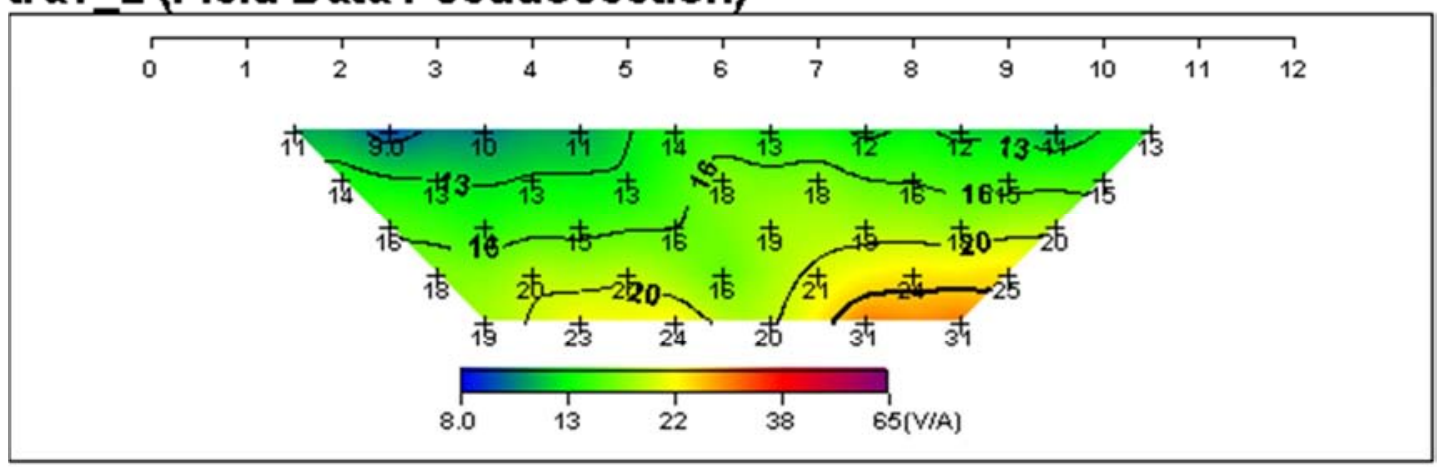

\section{trav_2 (Theoretical Data Pseudosection)}

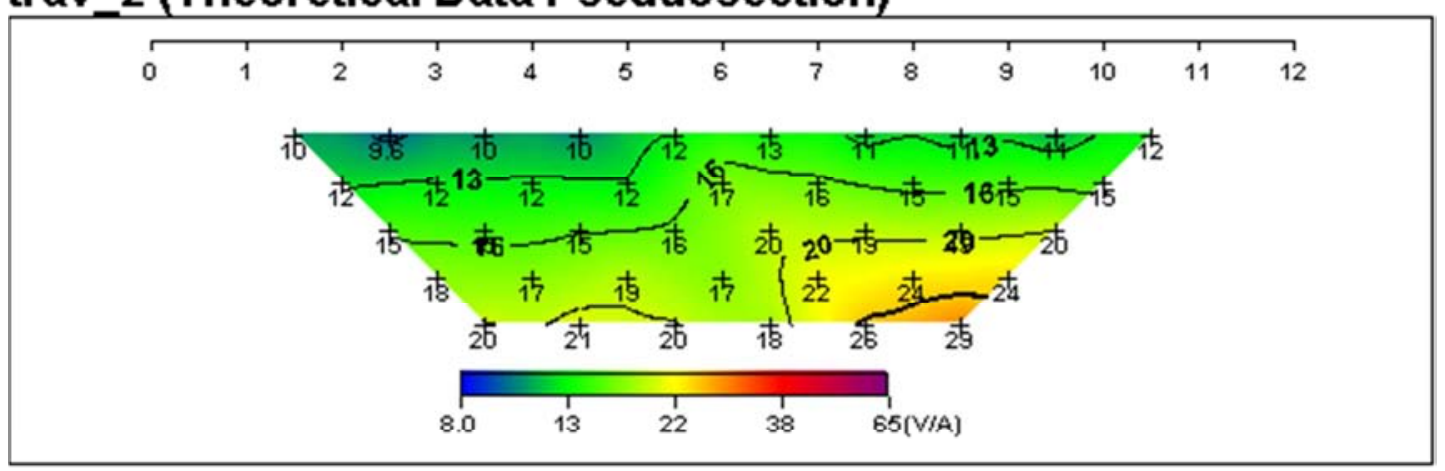

\section{trav_2 (2-D Resistivity Structure)}

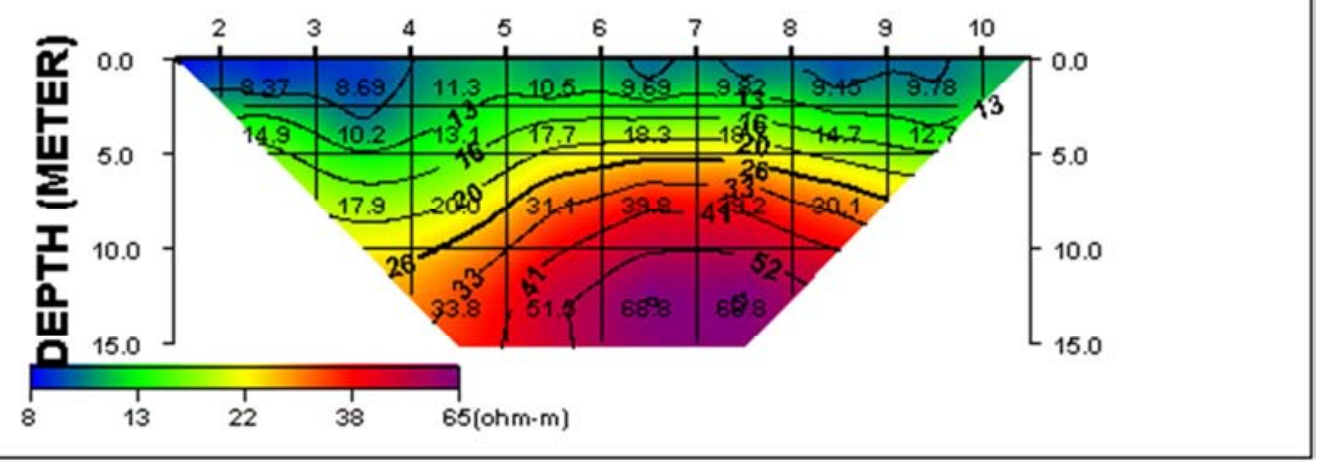

Figure 6. Inverted 2D Resistivity Section Along Traverse 2.

Traverse 3 (Figure 7) covers a total spread of $60 \mathrm{~m}$ with an electrode spacing of $5 \mathrm{~m}$ and runs in the N-S direction. The resistivity value ranges from $8.47 \Omega \mathrm{m}$ to $53.5 \Omega \mathrm{m}$ along the traverse. Four major layers are observed in this $2 \mathrm{D}$ resistivity structure. The first layer (blue colour) is observed at the two edges of the traverse at the western edge with resistivity value ranging from $8.59 \Omega \mathrm{m}$ to $8.61 \Omega \mathrm{m}$ observed between stations 2 to 4 and eastern edge with resistivity value ranging from $9.25 \Omega \mathrm{m}$ to $9.47 \Omega \mathrm{m}$ and observed between stations 8 to 10 , covering a depth of about $2 \mathrm{~m}$, and which reveal peat/unconsolidated wet clay, with a discontinuity between stations 5 to 7 . The second layer (Green) has resistivity value ranging from $12.2 \Omega \mathrm{m}$ to $15.0 \Omega \mathrm{m}$, which reveals clay, has a depth to about $6 \mathrm{~m}$ across the traverse line with the exception of stations 2 to 4 and 8 to 10 . The third layer (Red) has a resistivity value ranging from $31.5 \Omega \mathrm{m}$ to $36.8 \Omega \mathrm{m}$ occurring a depth between $5 \mathrm{~m}$ downwards to the depth probed, revealing clay/ sandy clay formation. The fourth layer (purple) has resistivity value ranging from $44.5 \Omega \mathrm{m}$ to $53.5 \Omega \mathrm{m}$ and reveals sandy clay.

Generally, traverse 3 appears to have an extensive clay formation which is generally not good enough for engineering purposes. But notwithstanding, light structures could also be recommended with little excavation to a depth of about $3 \mathrm{~m}$ between stations 5 and 7 Stations between and 8 to 10 should be avoided for any engineering structure and if it is to be used it must be with a deep foundation. 


\section{trav_3 (Field Data Pseudosection)}

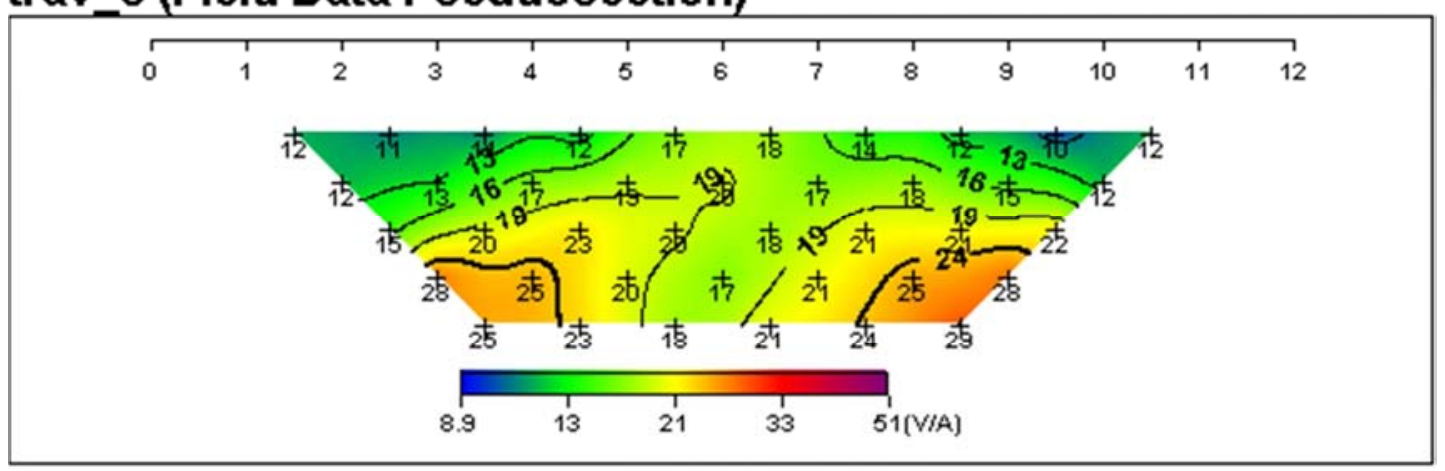

\section{trav_3 (Theoretical Data Pseudosection)}

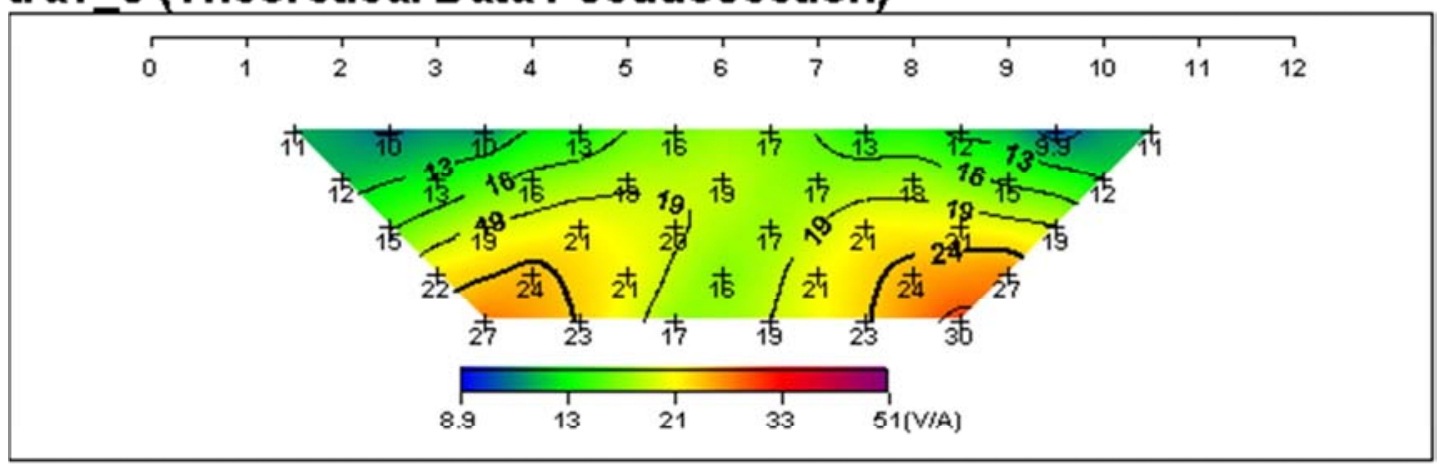

\section{trav_3 (2-D Resistivity Structure)}

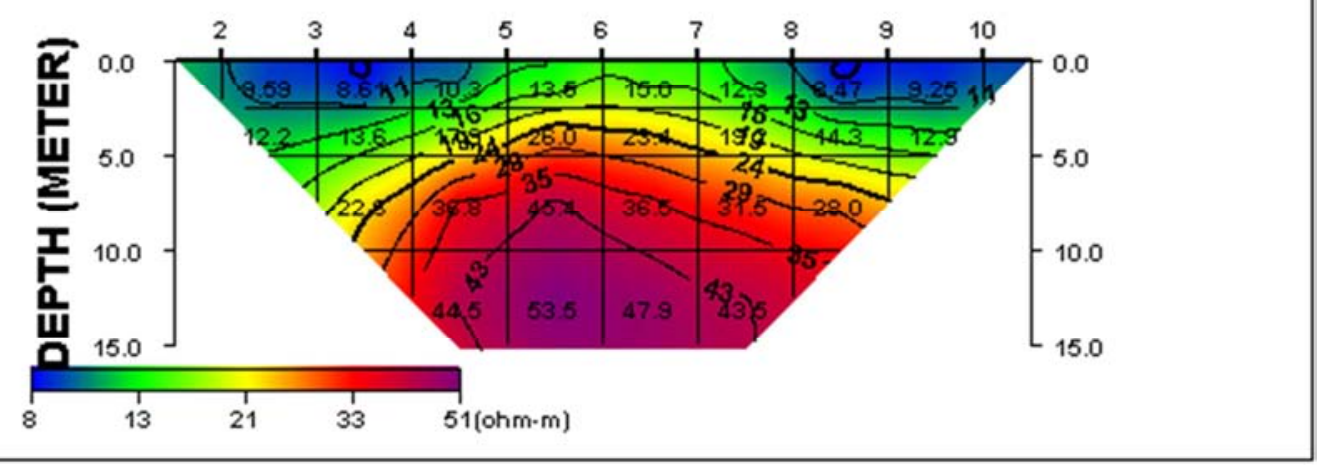

Figure 7. Inverted 2D Resistivity Section Along Traverse 3.

Traverse 4 (Figure 8) covers a total spread of $60 \mathrm{~m}$ with an electrode spacing of $5 \mathrm{~m}$ and runs in the N-S direction. The resistivity value ranges from $7.69 \Omega \mathrm{m}$ to $93.6 \Omega \mathrm{m}$ along the traverse. Four major layers are observed in this $2 \mathrm{D}$ resistivity structure. The first layer (blue colour) is observed at the two edges of the traverse, at the western edge with resistivity value ranging from $9.06 \Omega \mathrm{m}$ to $10.3 \Omega \mathrm{m}$ observed between stations 3 to 4 and eastern edge with resistivity value ranging from $7.69 \Omega \mathrm{m}$ to $8.70 \Omega \mathrm{m}$ and observed between stations 9 to 10 , covering a depth of about $2 \mathrm{~m}$, and which reveal peat/unconsolidated wet clay, with a discontinuity between stations 5 to 7 . The second layer (Green) has resistivity value ranging from $12.6 \Omega \mathrm{m}$ to $22.9 \Omega \mathrm{m}$, which reveals clay, has a depth to about $7 \mathrm{~m}$ across the traverse line with the exception of stations 5 to 7 where the depth is about $4 \mathrm{~m}$. The third layer (Red) has a resistivity value ranging from $46.4 \Omega \mathrm{m}$ to $54.0 \Omega \mathrm{m}$ occurring a depth between $5 \mathrm{~m}$ downwards to the depth probed, revealing clay/ sandy clay formation. The fourth layer (purple) has resistivity value ranging from $74.6 \Omega \mathrm{m}$ to $93.6 \Omega \mathrm{m}$ and reveals sandy clay.

Generally, traverse 3 appears to have an extensive clay formation which is generally not good enough for engineering purposes. Meanwhile, light structures could also be recommended with little excavation to a depth of about $3 \mathrm{~m}$ between stations 5 and 7 . Stations between 3 to 4 and 8 to 10 should be avoided for any engineering structure and if it is to be used, it must be with a deep foundation. 


\section{trav_4 (Field Data Pseudosection)}

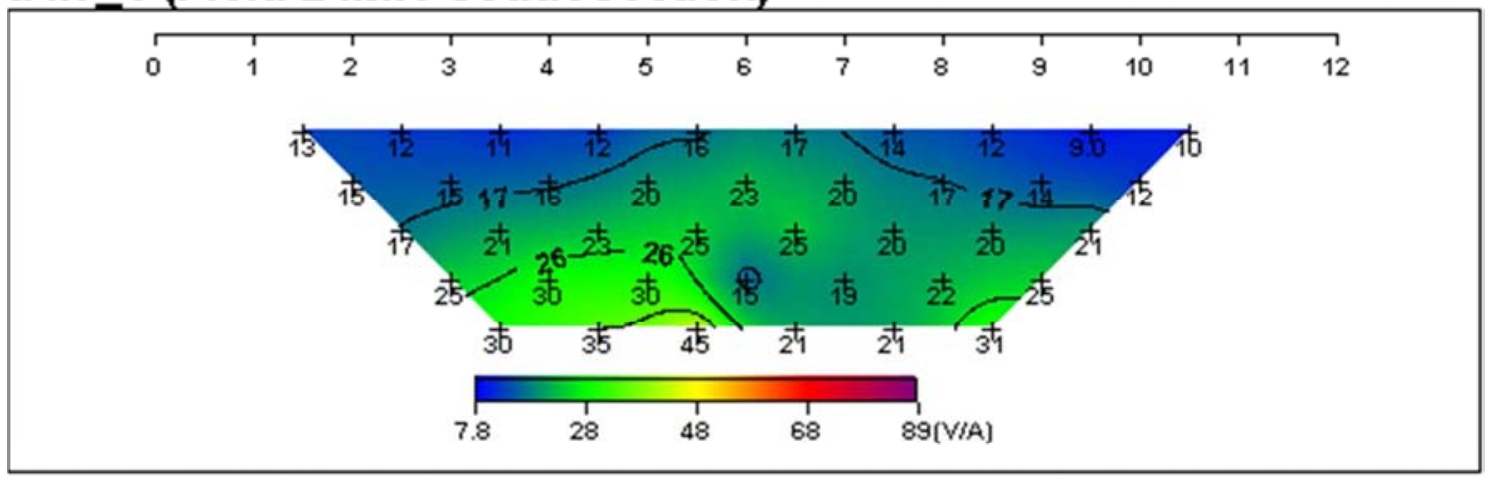

\section{trav_4 (Theoretical Data Pseudosection)}

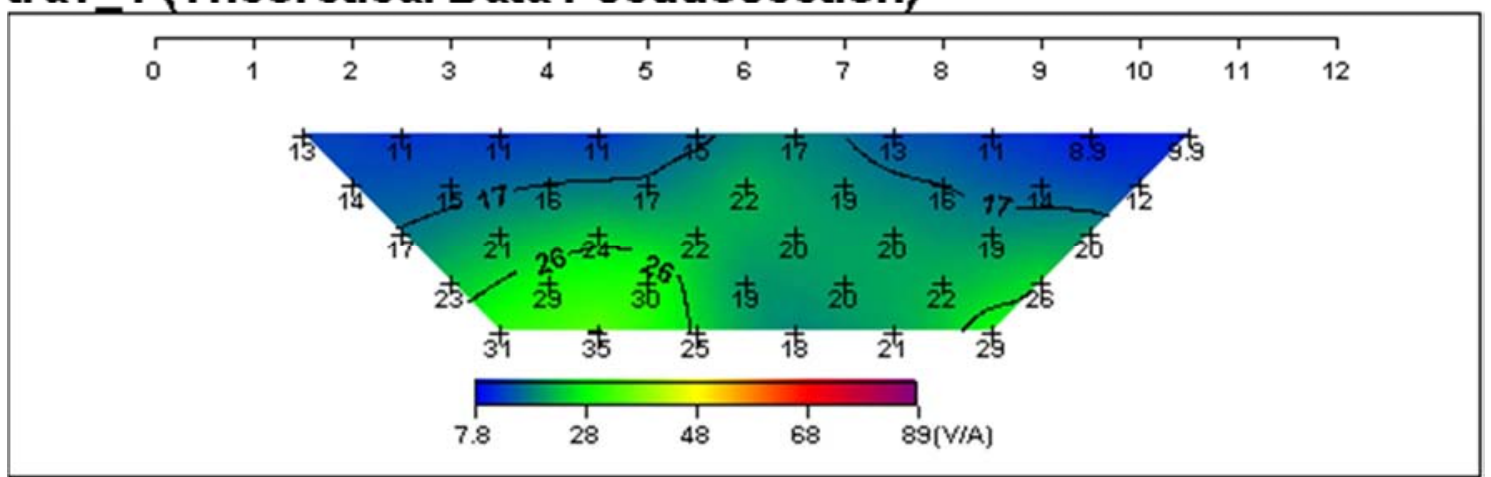

\section{trav_4 (2-D Resistivity Structure)}

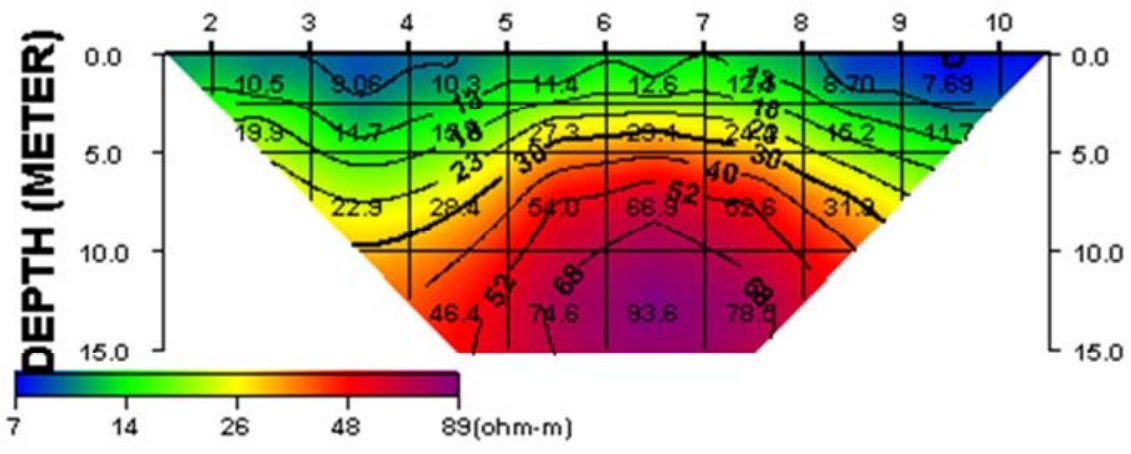

Figure 8. Inverted 2D Resistivity Section Along Traverse 4.

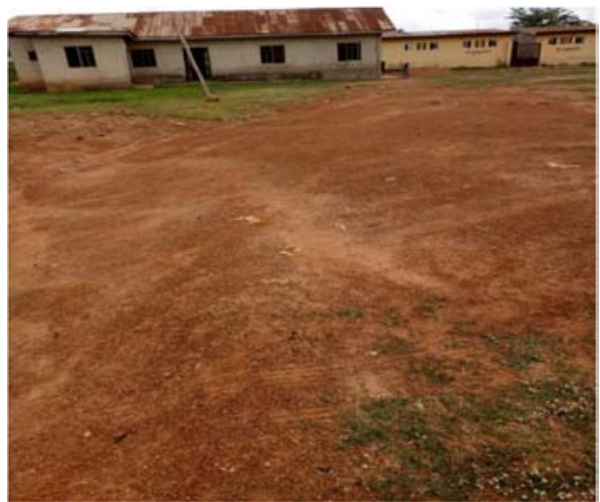

Figure 9. Distressed Building in the northwestern part of the Study area.

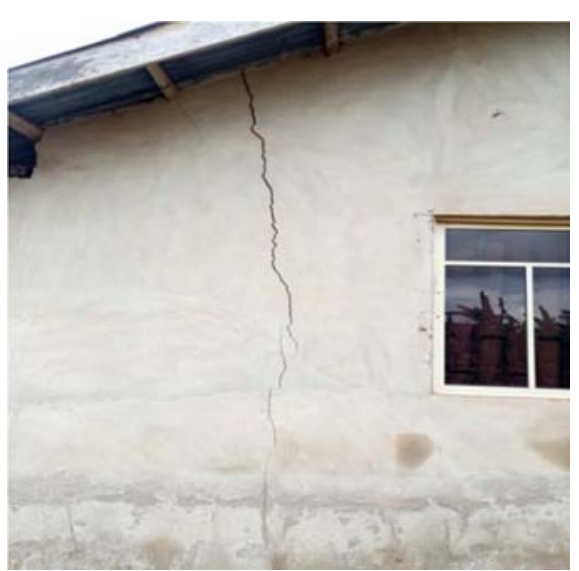

Figure 10. Distressed Building in the northwestern part of the Study area. 
Figures $5-8$ shows the general conditions of the site investigated. The four traverses established showed that the mid-point (stations 5 to 7 ) remains viable for light engineering constructions inspite of the area been underlain by clay formation. The northwestern and northeastern part remains not suitable enough for engineering purposes because of its observed weak zone (peat/unconsolidated wet clay). This probably accounted for the observed structural failures (Figures 9 and 10) near the site investigated.

\subsection{Vertical Elecctrical Sounding (VES)}

To remove unwanted signals and enhance the signal qualities, the VES data were processed using WinResist (1D inversion software). The results are presented as resistivity curves (Figures 11-14). The inspection of the sounding curves revealed the different geoelectric layers in terms of their resistivities and depths in the study area. A total of three geoelectric layers were delineated reflecting lithological variations with depth. The nature of the curve types suggests that the measured resistivities vary with depth of investigation in the study area. For the four VES curves (VES 1, 2, 3 and 4), the first layer which is the top soil (interpreted to be peat/wet clay) has resistivities ranging between $97 \Omega \mathrm{m}$ to $221 \Omega \mathrm{m}$ occurring to a depth between $0.4 \mathrm{~m}$ to $1.1 \mathrm{~m}$. The second layer has resistivities ranging between $8 \Omega \mathrm{m}$ to $12 \Omega \mathrm{m}$, with layer thickness between $3.8 \mathrm{~m}$ to $7.4 \mathrm{~m}$ occurring at depth between $4.9 \mathrm{~m}$ to $7.9 \mathrm{~m}$. This layer is interpreted to be clay. The third layer is the assumed basement which is interpreted as sandy clay with resistivities ranging between $214 \Omega \mathrm{m}$ to $641 \Omega \mathrm{m}$. The summary of the VES results is as shown in table 1. The VES results, actually confirm the result obtained from the $2 \mathrm{D}$ resistivity imaging, showing the second layer where the foundation is supposed to be laid, to be an expansive clay formation. And because of its thickness, light engineering structures are recommended. The geoelectric section generated (Figure 15) also supported how thick the clay formation in layer two is and also why it is dangerous to put any structure on the northwestern part of the study area (Figure 15).
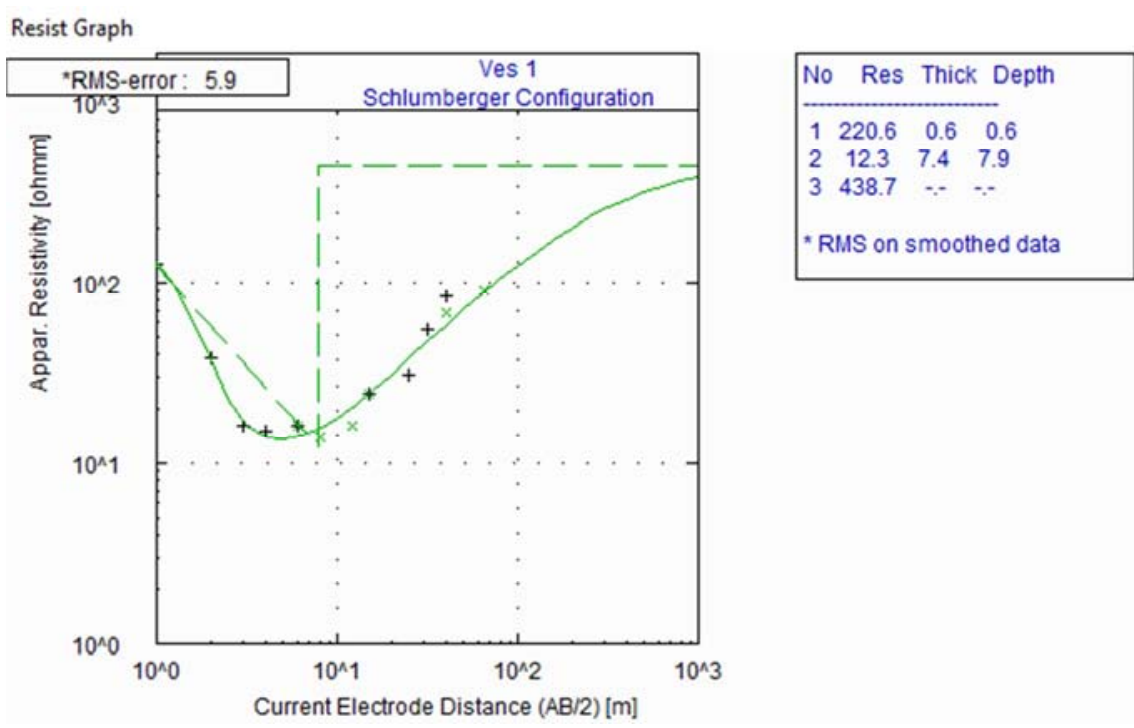

Figure 11. The Schlumberger Depth Sounding beneath VES1.
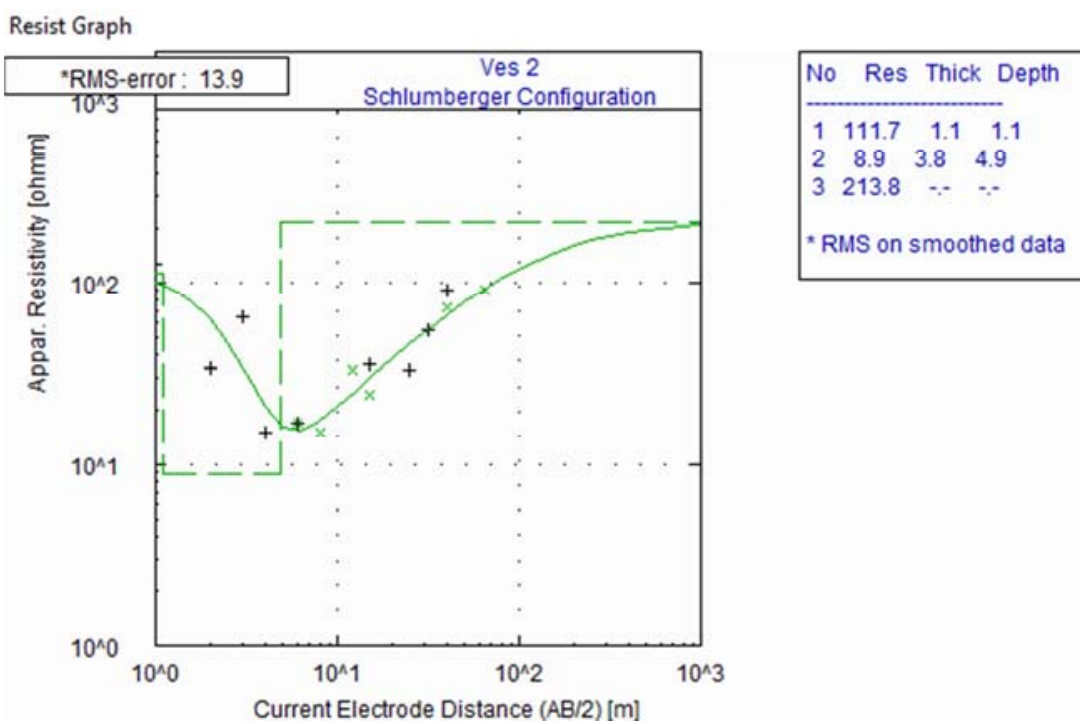

Figure 12. The Schlumberger Depth Sounding beneath VES2. 


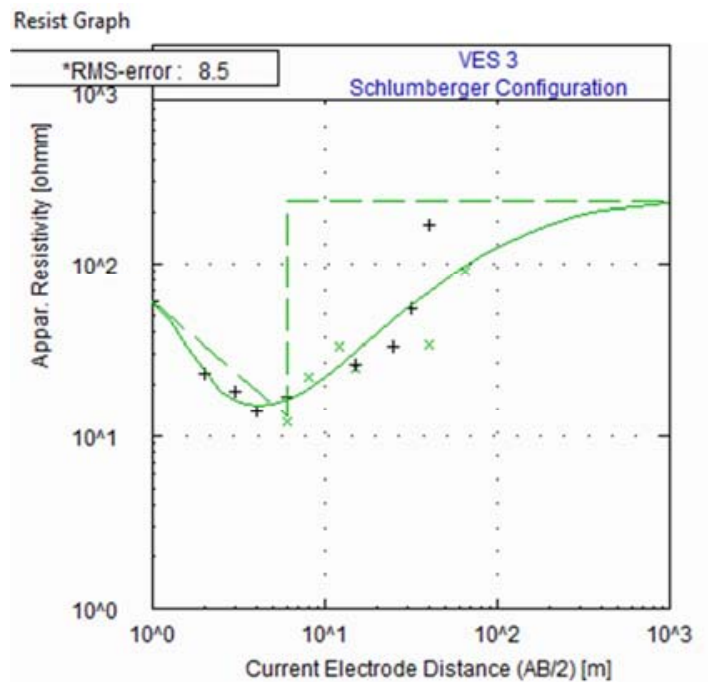

\begin{tabular}{|llll}
\hline No & Res & Thick & Depth \\
\hline 1 & 96.7 & 0.6 & 0.6 \\
2 & 13.0 & 5.5 & 6.1 \\
3 & 230.7 & $\because$ & $\because$ \\
* RMS on smoothed data
\end{tabular}

Figure 13. The Schlumberger Depth Sounding beneath VES3.

Resist Graph

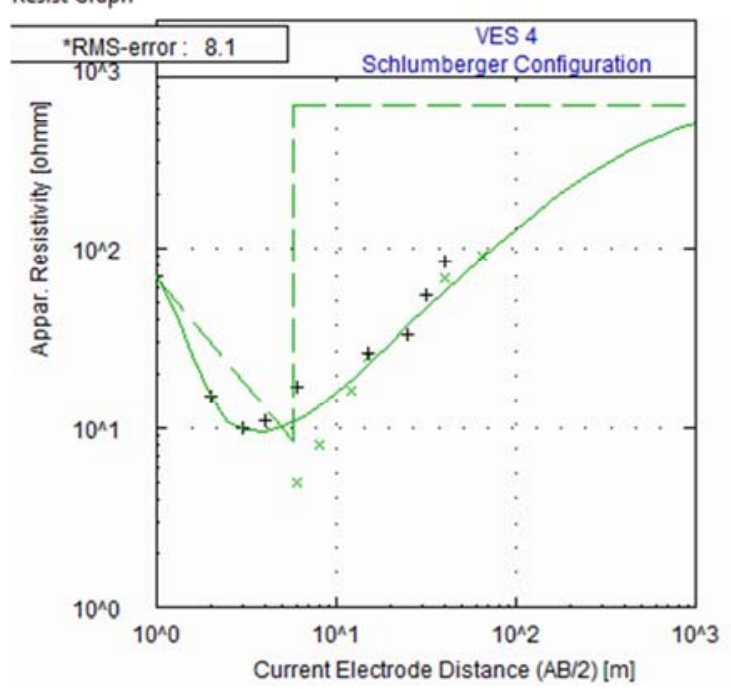

\begin{tabular}{|lcccc}
\hline No & Res & Thick & Depth \\
\hline 1 & 178.1 & 0.4 & 0.4 \\
2 & 8.4 & 5.4 & 5.8 \\
3 & 640.6 & $\ddots$ & $\ddots-$ \\
& & & & \\
* RMS on smoothed data
\end{tabular}

Figure 14. The Schlumberger Depth Sounding beneath VES4.

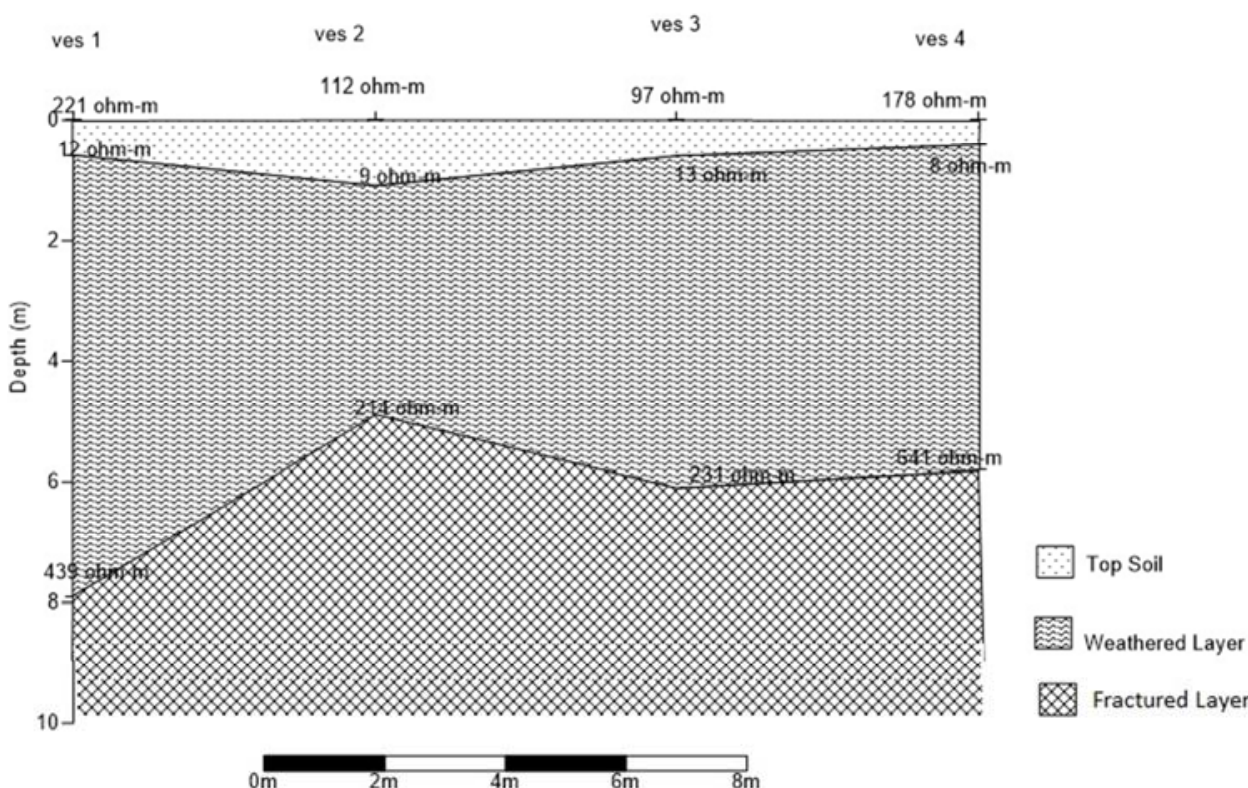

Figure 15. Geoelectric Section of the Study Area. 
Table 1. Summary of the VES Interpretation Results.

\begin{tabular}{lllllll}
\hline VES NO & LAYER NO & RESISTIVITY $(\mathbf{O h m}-\mathbf{m})$ & THICKNESS (M) & DEPTH (M) & CURVE TYPE & Lithological units \\
\hline 1 & $1,2,3$ & $221,12,439$ & $0.6,7.4,-$ & $0.6,7.9,-$ & $\mathrm{H}$ & Topsoil Clay Fractured Layer \\
2 & $1,2,3$ & $112,9,214$ & $1.1,3.8,-$ & $1.1,4.9,-$ & $\mathrm{H}$ & Topsoil Clay Fractured Layer \\
3 & $1,2,3$ & $97,13,231$ & $0.6,5.5,-$ & $0.6,6.1,-$ & $\mathrm{H}$ & Topsoil Clay Fractured Layer \\
4 & $1,2,3$ & $178,8,641$ & $0.4,5.4,-$ & $0.4,5.8,-$ & $\mathrm{H}$ & Topsoil Clay Fractured Layer \\
\hline
\end{tabular}

\section{Conclusion}

An integrated survey using VES and 2D (Wenner arrays) has been carried out at a pre-engineering construction site in Akure, in order to ascertain its competence and suitability for engineering structures. The results of both VES and 2D imaging revealed that the subsurface is made up of top siol (Peat/wet clay), clay and sandy clay. The study has revealed that shallow foundation may not be feasible or advisable for massive engineering or super structures because of the presence of clay materials that are close to the surface (Table 1). But small or light engineering structures could be recommended.

\section{References}

[1] Ogumgbe, A. S., Balogun, A. R., Umar, A. A and Adejo, O. A. (2017): Site Characterization Using Electrical Resistivity Methods: A Case Study of Iba Nursery/Primary School, Ojo, Southwest, Nigeria. Journal of Scientific Research \& Reports, Vol.13 No.1 Pp1-16.

[2] Aderoju, A. A., and Adebayo, O. O. (2015): Geophysical Investigation for Foundation Studies at Ogudu River Valley Estate, Lagos, Southwestern, Nigeria. The pacific Journal of Science and Technology. Vol.15, No.1, Pp295-304.

[3] Iwueze E. S. (2018): Subsoil Characterization For Construction Purpose Using Integrated Geophysical Methods. Unpublish M. Tech. seminal paper submitted to the Department of Applied Geophysics, Federal University of Technology, Akure, Nigeria.

[4] Tigistu, H. and Alemayehu, A. (2014): Resistivity Tomography and Magnetic Surveys: applications For Building Site Characterization at Gubre, Wolkite University Site, western Ethiopia. SINET: Ethiop. J. Sci., 37 (1): 13-30.

[5] Cyril, C. O. "2D Resistivity imaging and Geotechnical investigation of structural collapsed Lecture Theatre in Adekunle Ajasin University, Akungba-Akoko, Southwestern, Nigeria". Environmental Research, Engineering and Management, No. 3 (69), pp. 49-59, 2014.

[6] Nordiana, N. M., Bery, A. A., Taquiddin, Z. M., Jinmin, M. and Abri, I A. (2018): 2-D Electrical Resistivity Tomography (ERT) assessment of Ground Failure in Urban area. Journal of Physics: Conf. series 995, (012076). Doi: 10.1088/17426596/995/1/012076, Pp1-8.
[7] Bayowa, O. G. and Olayiwola, N. S. (2015): "Electrical resistivity investigation for Topsoil Thickness, Competence and Corrosivity Evaluation: A case study from Ladoke Akintola University of Technology, Ogbomoso, Nigeria". $20152^{\text {nd }}$ International Conference on Geological and Civil engineering. IPCBEE Vol.80 (2015) LACSIT press, Singapore. DOI: 10.7763/IPCBEE, 2015.v80.11.

[8] Ayolabi, E. A., Folorunso, A. F. and Jegede, O. E. (2012): An application of 2D Electrical Resistivity Tomography in Geotechnical Investigations of Foundation Defects. A case Study. Journal of Geology and Mining Research. Vol.3 (12) Pp. 142-151.

[9] Sunmonu, L. A., Alagbe, O. A., Mabunmi, S. A., Adeniji, A. A. and Olasunkanmi, N. K. (2013): Geophysical Investigation into the Cause (s) of Structural Failure within Bacosa and Faculty of Science Buildings, Bowen University Temporary site, Iwo. Advances in Physics Theories and applications. Vol.25, Pp1-17.

[10] Alagbe, O. A., Sanusi, S. O. and Bamigboye, A. A: (2019): 2D Electrical Resistivity Prospecting for Groundwater at the Premises of the Staff Quarters of Elizade University, Ilara Mokin, Ondo state Nigeria. World Journal of Innovative Research (WJIR). Volume 6, Issue 2, Pp 100-108.

[11] Alagbe, O. A. (2018): 2D Geoelectrical Resistivity Imaging for the Assessment of Subsurface Soil Corrosivity Zones at a Proposed Filling Station Site in Akure Southwestern Nigeria. International Advanced Research Journal in Science, Engineering and Technology. Vol. 5, Issue 11.

[12] Falae, P. O. (2014): Application of Electrical Resistivity in Buildings Foundation Investigation in Ibese Southwestern Nigeria. Asia Pacific Journal of Energy and Environment, Vol.1, No.2, PP95-107.

[13] Rungroj, A. and Mark, E. E. (2015): Application of 2D Electrical resistivity Tomography to Engineering Projects: Three Case Studies. Songklanakarin J. Sci. Technol. 37 (6), 675-681.

[14] Rahman, M. A. 1976. Review of the basement geology of southwestern Nigeria. In C. A. Kogbe (Editor). In Geology of Nigeria (pp 41-58). Lagos: Elizabethan publishing Co.

[15] Adeyemo, I. A., Akande, V. D., Ajayi-Gidi, O. and Aremo, F. O. (2015): Geophysical Investigation of Impact of Geologic Structure on Preferred Percolating Paths of an Oil-based Leachate within a Migmatite-Gneiss Environment: A Case Study of Federal University of Technology, Akure Campus Nigeria. Journal of Environment and Earth Sciences. Vol.5, No.14, Pp65-75. 